\title{
Effect of Cage Density on the Performance of 25- to 84-Week-Old Laying Hens
}

- Author(s)
Rios $\mathrm{RL}^{1}$
Bertechini $\mathrm{AG}^{2}$
Carvalho $\mathrm{CC}^{3}$
Castro $\mathrm{SF}^{3}$
Costa VA
1 Post-graduation student EV/UFMG.
2 Head Professor- Universidade Federal de
Lavras.
3 Post-graduation students - Universidade
Federal de Lavras.
Animal Science Department
Universidade Federal de Lavras

Mail Address
A.G. Bertechini
Departamento de Zootecnia
Universidade Federal de Lavras
Campus Universitário
37200-000. Lavras, MG, Brazil
Phone:35-38291240
E-mail: bertechini@dzo.ufla.br

\section{Keywords}

Birds per cage, cage density, egg production, laying hens.

\section{ABSTRACT}

Three experiments were carrie out to evaluate the influence of cage density on the performance of 25- to 84-week-old laying hens. Forty hundred Lohmann-LSL layers were distributed in cages $(100 \times 40 x$ $45 \times 50 \mathrm{~cm})$ according to a completely randomized experimental design with split plot in time.Three treatments $(10,12$, or 14 hens per cage, corresponding, to 450,375, and $321 \mathrm{~cm}^{2} /$ bird, respectively), with 15 assessment periods (four weeks each), and eight replicates per treatment were applied. Considering that layer's production cycle is affected by age, three experimental trials ( 25 to $44 ; 45$ to 64 and 65 to 84 weeks of age) were carried out, and the data collected in each trial was individually analyzed. Increasing cage density significantly reduced feed intake in all phases studied. Increasing birds $/ \mathrm{cm}^{2}$ significantly decreased feed intake and improved feed conversion at all stages of study, and egg production was only affected in 45-week-old birds. The number of birds per cage should be reduced as birds age in order not to affect their performance. Birds with more cage space in the presented higher feed intake; however, this did not result in higher egg production or lower mortality. These results suggest that up to 45 weeks of age, $375 \mathrm{~cm}^{2}$ per layer results in the best performance, and from then on, $450 \mathrm{~cm}^{2}$ per bird is required to maintain egg production and to reduce hen mortality.

\section{INTRODUCTION}

High bird density is often used in layer production to reduce housing and equipment costs per bird. However, this may influence flock performance, as it may cause significant bird stress, impairing bird welfare. Excessive reduction of cage space as well as feeder and drinker space may have negative impact on layer growth and performance, as feed intake may be reduced, with consequent decrease in live weight, and in muscle and skeletal development. Body weight and feed intake are essential factors when assessing bird's development, as well as egg production, egg size, and feed conversion ratio.

A common practice in Brazil and in the United States is to increase the number of birds per cage to reduce production costs. At the same time, the layer strains currently available in the market have been submitted to continuous genetic improvement. Layers have become increasingly lighter and more productive, and therefore, further studies on bird density are warranted. Few studies have been conducted on the effects of bird density during the growing period on bird performance this phase and the next rearing phase. Due to the intensification of the production process in industrial scale, with reduced income per housed bird and lower profit margins, cage density has become a factor of great economic importance.
Arrived: October/2009

Approved: December/2009 


\section{Rios RL, Bertechini AG, Carvalho JCC, Castro SF, Costa VA}

This study aimed at evaluating the effect of bird density in cages during lay ( 25 to 84 weeks of age) on layer performance.

\section{MATERIAL AND METHODS}

The experiment was carried out at the Poultry Sector of the Federal University of Lavras (Universidade Federal de Lavras). Four hundred (400) 18-week-old Lohmann-LSL layers from the same flock were purchased. Upon arrival at the experimental facilities, birds were weighed and distributed according to three different bird densities:10,12, or 14 birds per cage (100 $\mathrm{cm}$ wide $\times 45 \mathrm{~cm}$ deep $\times 40 \mathrm{~cm}$ high height, with a 50 $\mathrm{cm}$ partition), which corresponded respectively to 450 , 375 , and $321 \mathrm{~cm}^{2} / \mathrm{bird}$. Two hundred and eighty eight (288) birds out of the 400 were utilized; the remaining 112 birds were, housed at the same experimental densities in order to replace any possible bird that died during the experimental period. Birds were housed a $20 \mathrm{~m}$ long $\times 6 \mathrm{~m}$ wide poultry house measuring $20 \mathrm{~m}$ long by $6 \mathrm{~m}$ broad, where the metal cages, equipped with nipple drinker and a trough feeder, were placed. A completely randomized experimental design in split plot in time was applied. Each plot (treatment) consisted of three cage densities of eight replicates each, and the subplots included fifteen production periods ( 25 to $28 ; 29$ to $32 ; 33$ to $36 ; 37$ to 40 , and 41 to 44 weeks of age in the first trial; 45 to $48 ; 49$ to 52 ; 53 to $56 ; 57$ to 60 ; and 61 to 64 weeks of age in the second trail and 65 to $68 ; 69$ to $72 ; 73$ to $76 ; 77$ to 80 and 81 to 84 weeks of age in the third trial). Bird mortality and egg production were daily recorded in proper forms. Dead birds were replaced by the birds housed in the replacement cages at the same density equal to that of the plot where death occurred. All birds were fed twice daily with the same diet, formulated according to the recommendations of the strain's manual (1999). A lighting program of 16 of light per day was applied. Feed intake, egg production, and mortality were weekly recorded.

The collected data were analyzed using SISVAR statistical package (Ferreira, 2000). The following parameters were evaluated: feed intake, egg production, average egg weight, feed conversion per $\mathrm{kg}$ ( $\mathrm{kg}$ feed/ kg eggs), feed conversion per dozen ( $\mathrm{kg}$ feed/dozen eggs), and mortality.

\section{RESULTS AND DISCUSSION}

Table 1 shows the results obtained for, the phase
Effect of Cage Density on the Performance of 25- to 84Week-Old Laying Hens

of 25 to 44 weeks of age.There was no effect of the cage density ( $p>0.05$ ) on egg production or egg weight. These results are consistent with those obtained by Marks et al. (1970), who evaluated, three cage densities $\left(1,125,562\right.$,or $450 \mathrm{~cm}^{2} /$ bird) and did not find any, differences in egg production. Other authors, such as Dorminey \& Arscott (1971), Wells (1971), Craig \& Milliken (1989), Lee (1989), and Carey et al. (1995), also did not observe any effect of cage density on egg production. However, opposite findings were reported by Cunningham et al. (1988), who verified $2.1 \%$ egg production reduction when cage density was increased from 406 to $316 \mathrm{~cm}^{2} /$ bird. Garcia et al. (1993), Adams \& Craig (1985), Davami et al. (1987) and Okpokho et al. (1987) also found that increasing cage density and reduction of feeder space/bird caused a decline in egg production. Egg weight results obtained in the present study were similar to those obtained by Al Rawi et al. (1976), Goodling (1984), Mench et al. (1986), Lee (1989), and Carey et al. (1995), who also did not find any effect of cage density on egg weight, whereas Roush et al. (1984), observed a trend of increasing egg weight as cage area per bird was reduced. Davami et al. (1987) found that egg weight decreased in the treatment of highest density. Cunningham (1982), however, reported that the densities of 483.87 and $387.09 \mathrm{~cm}^{2} / \mathrm{bird}$, in the "deep" cages, and of 484.15 and $387.32 \mathrm{~cm}^{2} /$ bird in the shallow cages did not reduce egg weight.

Period of lay $(p<0.01)$ influenced average egg production and egg weight (Table 1). Egg production followed the curve described in the strain's manual, reaching a plateau, and declining thereafter. The increase in egg weight is related to the increase in feed intake by the birds according to their normal growth cycle.

Feed intake results (Table 1 ) were significantly influenced by the, interaction $(p<0.01)$ between period of lay and cage density, with increasing feed intake in each cage density as a function of bird age. A significant difference $(p<0.01)$ in feed intake was determined within the studied periods among cage densities, with birds housed at the density of $321 \mathrm{~cm}^{2}$ / bird presenting the lowest feed intake. These results are similar to these obtained by Hill (1977), who housed layers at, densities of 310,38 , and $464 \mathrm{~cm}^{2} /$ bird and, found that those housed at the density of $310 \mathrm{~cm}^{2} /$ bird consumed less feed than those housed at 387 and $464 \mathrm{~cm}^{2} / \mathrm{bird}$.

There was a significant effect of the interaction $(p<0.01)$ between period of lay and cage density on 
Rios RL, Bertechini AG, Carvalho JCC, Castro SF, Costa VA
Effect of Cage Density on the Performance of 25- to 84Week-Old Laying Hens feed conversion per $\mathrm{kg}$. The only density affected by period was $375 \mathrm{~cm}^{2} /$ bird $(p<0.01)$, increase in feed intake was not accompanied by increase in egg weight as layers aged. Feed conversion ratio relative to cage density in periods 4 and 5 are consistent with those observed by Hill (1977), who found an improvement in feed conversion per kilogram when cage density increased from 464 to $310 \mathrm{~cm}^{2} / \mathrm{bird}$. On the other hand, Adams \& Craig (1985), Davami et al. (1987), Cunningham \& Ostrander (1982), and Garcia et al. (1993) observed an improvement in feed conversion per dozen and per kilogram of produced eggs as the, available space per bird in the cage increased (lower density).

Mortality is controversial when associated to housing density, because it is believed that mortality increases with increasing density, as observed in the present experiment, which mortality rates were of $1.25,1.05$, and $6 \%$ as cage density increased.

The results of the period of 45 to 64 weeks are presented in Table 2. There was no effect of cage density ( $p>0.05)$ egg weight or feed conversion ratio (FCR kg/dz). However, cage density influenced feed intake $(p<0.05)$, egg production, and FCR $(\mathrm{kg} / \mathrm{kg})$. Feed intake increased as the number of birds pen cage decreased, with the lowest feed intake observed at the density of 14 birds per cage $\left(321 \mathrm{~cm}^{2} / \mathrm{bird}\right)$.

Birds housed at the lowest density presented the highest egg production, whereas the egg production of those housed at intermediate density was not different from the others.

FCR per $\mathrm{kg}$ was negatively affected by the lowest cage density, that is, the highest density $\left(321 \mathrm{~cm}^{2} / \mathrm{bird}\right)$ presented the poorest FCR.

These results are opposed to those verified by Lee (1989) and, Carey et al. (1995), who did not observe any effect of cage density on egg production/bird/day or per bird housed. On the other hand, results similar to the present study were reported by Cunningham et al. (1988), who observed $2.1 \%$ reduction in egg production/bird/day when density was increased from 406 to $316 \mathrm{~cm}^{2} / \mathrm{bird}$. Garcia et al. (1993) and Okpokho et al. (1987) also found that increasing cage density and reducing feeder space/bird decreased egg production.

Egg weight results of the present study were similar

Table 1 - Egg production (\%), feed intake (g/bird/day), egg weight (grams), feed conversion (g/g) and feed conversion per dozen (g/dz) of Lohmann-LSL layers between 25 to 44 weeks of age as a function of, period of lay and cage density (birds/cage).

\begin{tabular}{|c|c|c|c|c|c|c|c|}
\hline \multirow[t]{2}{*}{ Parameter } & \multirow[t]{2}{*}{ Density } & \multicolumn{5}{|c|}{ Periods ${ }^{1,2}$} & \multirow[b]{2}{*}{ Mean $^{3}$} \\
\hline & & 1 & 2 & 3 & 4 & 5 & \\
\hline \multicolumn{8}{|l|}{$\begin{array}{l}\text { Feed intake } \\
\text { (g/bird/day) }\end{array}$} \\
\hline \multirow[t]{4}{*}{$C \vee \%=2.51$} & 10 & $107 \mathrm{Ab}$ & $111 \mathrm{Aa}$ & $113 \mathrm{Aa}$ & $112 \mathrm{Aa}$ & $113 \mathrm{Aa}$ & 111.2 \\
\hline & 12 & $100 \mathrm{BC}$ & $107 \mathrm{Ab}$ & 109 Aab & $112 \mathrm{Aa}$ & $112 \mathrm{Aa}$ & 108.0 \\
\hline & 14 & 102 Bab & $99 \mathrm{Bb}$ & $102 \mathrm{Bab}$ & $105 \mathrm{Ba}$ & $105 \mathrm{Ba}$ & 102.6 \\
\hline & Mean & 103 & 105,6 & 108 & 109.6 & 110 & \\
\hline \multicolumn{8}{|c|}{ Egg production (\%) } \\
\hline \multirow[t]{4}{*}{$\mathrm{CV} \%=2.68$} & 10 & 95.03 & 95.64 & 97.26 & 94.77 & 94.33 & 95.41 \\
\hline & 12 & 94.42 & 95.64 & 95.87 & 93.39 & 91.88 & 94.23 \\
\hline & 14 & 95.19 & 92.69 & 95.06 & 92.40 & 92.46 & 93.56 \\
\hline & Mean & 94.88 & 94.66 & 96.06 & 93.52 & 92.87 & \\
\hline \multicolumn{8}{|l|}{ Egg weight (g) } \\
\hline \multirow[t]{4}{*}{$\mathrm{CV} \%=1.70$} & 10 & 62.77 & 63.47 & 65.38 & 66.08 & 66.47 & 64.83 \\
\hline & 12 & 62.37 & 63.56 & 65.37 & 66.14 & 66.69 & 64.82 \\
\hline & 14 & 62.95 & 63.95 & 65.21 & 67.14 & 67.69 & 65.39 \\
\hline & Mean & 62.69 & 63.66 & 65.32 & 66.45 & 66.95 & \\
\hline \multicolumn{8}{|l|}{$\begin{array}{l}\text { Feed } \\
\text { conversion, g/dz }\end{array}$} \\
\hline \multirow[t]{4}{*}{$C \vee \%=7.20$} & 10 & 1.38 & 1.45 & 1.44 & 1.53 & 1.48 & $1.45 a$ \\
\hline & 12 & 1.32 & 1.37 & 1.40 & 1.47 & 1.48 & $1.41 \mathrm{ab}$ \\
\hline & 14 & 1.31 & 1.28 & 1.29 & 1.44 & 1.44 & $1.35 b$ \\
\hline & Mean & 1.34 & 1.36 & 1.38 & 1.48 & 1.46 & \\
\hline \multicolumn{8}{|l|}{$\begin{array}{l}\text { Feed } \\
\text { conversion,g/g }\end{array}$} \\
\hline \multirow[t]{4}{*}{$C \vee \%=3.17$} & 10 & 1.76 & 1.80 & 1.77 & 1.79 & 1.78 & $1.78 a$ \\
\hline & 12 & 1.70 & 1.76 & 1.74 & 1.81 & 1.83 & $1.77 a$ \\
\hline & 14 & 1.70 & 1.72 & 1.70 & 1.72 & 1.72 & $1.71 \mathrm{~b}$ \\
\hline & Mean & 1.72 & 1.76 & 1.74 & 1.77 & 1.78 & \\
\hline
\end{tabular}

1 - Means followed by capital letters in the same column are statistically different by Tukey's test $(p<0.01) .2$ - Means followed by different small letters in the same row are statistically different by Tukey's test $(p<0.01) .3$ - Means followed by different small letters in the same column are statistically different by Tukey's test $(p<0.01)$. 
Rios RL, Bertechini AG, Carvalho JCC, Castro SF, Costa VA
Effect of Cage Density on the Performance of 25- to 84Week-Old Laying Hens

\begin{tabular}{|c|c|c|c|c|c|c|c|}
\hline \multirow[t]{2}{*}{ Parameter } & \multirow[t]{2}{*}{ Density } & \multicolumn{5}{|c|}{ Periods } & \multirow[b]{2}{*}{ Mean $^{1}$} \\
\hline & & 1 & 2 & 3 & 4 & 5 & \\
\hline \multicolumn{8}{|l|}{$\begin{array}{l}\text { Feed intake } \\
\text { (g/bird/day) }\end{array}$} \\
\hline \multirow[t]{4}{*}{$C V \%=3.73$} & 10 & 115.88 & 111.72 & 105.21 & 109.71 & 110.92 & $110.68 \mathrm{~b}$ \\
\hline & 12 & 112.23 & 109.68 & 106.27 & 108.66 & 107.77 & $108.92 b$ \\
\hline & 14 & 110.32 & 106.74 & 102.06 & 100.52 & 100.27 & $103.98 \mathrm{a}$ \\
\hline & Mean & 112.81 & 109.38 & 104.51 & 106.25 & 106.32 & \\
\hline \multicolumn{8}{|c|}{ Egg production (\%) } \\
\hline \multirow[t]{4}{*}{$C V \%=3.64$} & 10 & 94.33 & 93.48 & 91.65 & 92.41 & 92.86 & $92.94 \mathrm{~b}$ \\
\hline & 12 & 91.11 & 92.45 & 91.67 & 91.67 & 91.48 & $91.67 \mathrm{ab}$ \\
\hline & 14 & 92.00 & 90.18 & 90.02 & 89.64 & 88.54 & 90.07 a \\
\hline & Mean & 92.48 & 90.03 & 91.11 & 91.24 & 90.96 & \\
\hline \multicolumn{8}{|l|}{ Egg weight (g) } \\
\hline \multirow[t]{4}{*}{$C V \%=1.54$} & 10 & 66.48 & 67.00 & 66.23 & 67.19 & 67.17 & 66.81 \\
\hline & 12 & 66.69 & 66.77 & 66.25 & 67.40 & 65.92 & 66.60 \\
\hline & 14 & 67.70 & 67.61 & 67.09 & 67.38 & 67.01 & 67.35 \\
\hline & Mean & 66.95 & 67.12 & 66.51 & 67.32 & 66.70 & \\
\hline \multicolumn{8}{|c|}{ Feed conversion, $\mathrm{g} / \mathrm{dz}$} \\
\hline \multirow[t]{4}{*}{$C V \%=4.09$} & 10 & 1.48 & 1.43 & 1.38 & 1.42 & 1.44 & 1.43 \\
\hline & 12 & 1.48 & 1.42 & 1.39 & 1.42 & 1.41 & 1.42 \\
\hline & 14 & 1.44 & 1.42 & 1.36 & 1.35 & 1.36 & 1.38 \\
\hline & Mean & 1.46 & 1.42 & 1.37 & 1.39 & 1.40 & \\
\hline \multicolumn{8}{|c|}{ Feed conversion, g/g } \\
\hline \multirow[t]{4}{*}{$C V \%=4.03$} & 10 & 1.85 & 1.78 & 1.73 & 1.77 & 1.78 & $1.78 \mathrm{~b}$ \\
\hline & 12 & 1.85 & 1.78 & 1.75 & 1.76 & 1.79 & $1.78 \mathrm{~b}$ \\
\hline & 14 & 1.77 & 1.75 & 1.69 & 1.67 & 1.70 & $1.71 \mathrm{a}$ \\
\hline & & Mean 1.82 & 1.77 & 1.72 & 1.73 & 1.75 & \\
\hline
\end{tabular}

1 - Means followed by different small letters in the same row are statistically different by Tukey's test ( $p<0.05)$.

to those obtained by Lee (1989) and Carey et al. (1995), who also did not find any effect of density on egg weight, as opposed to Roush et al. (1984), who observed a trend of increasing egg weight as cage area per bird was reduced. Davami et al. (1987) verified that egg weight was reduced in the treatment with the highest cage density. Cunningham (1982), however, reported that densities of 483.87 and $387.09 \mathrm{~cm}^{2} / \mathrm{bird}$ in deep cages and of 484.15 and $387.32 \mathrm{~cm}^{2} /$ bird, in shallow cages did not influence egg weight.

The results obtained from 65 to 84 weeks are presented in Table 3. There was no effect of cage density ( $p>0.05$ ) on egg weight or feed conversion per $\mathrm{kg}$ eggs. However, a significant effects $(p<0.05)$ were detected on egg production, FCR per dozen and feed intake. The highest bird density (14 birds/cage or $321 \mathrm{~cm}^{2} / \mathrm{bird}$ ) negatively influenced egg production as compared to the densities of 10 or 12 birds per cage. This may be explained to the lower stress to which birds housed at the lowest density were submitted. Also, there was a linear effect $(p<0.05)$ of age, with decreasing in egg production as birds aged.

In terms of egg weight and FCR per kg eggs, there was linear effect $(p<0.05)$ of period of lay, with increase in egg weight and a stability after the second period.
Also, FCR per dozen and per kilogram eggs linearly increased with bird age, which may explained by the fact that egg production is reduced and egg weight is stabilized as layers age .

Cage density significantly influenced FCR per dozen eggs, with the density of 10 birds per cage presenting the poorest FCR due to their highest feed intake, whereas the other densities (12 and 14 birds per cage) presented no differences for this parameter.

There was significant effect of the interaction $(p<0.05)$ between period of lay and cage density on feed intake. During the first period, layers housed at the density of 10 birds per cage consumed more feed than those maintained at the other evaluated densities, which did not present different feed intake. As for the second period, feed intake was different only between the densities 10 and 14 birds per cage, with birds at the lowest density (10 birds/cage) presenting higher feed intake both during the fourth and the fifth periods (77 to 80 and 81 to 84 weeks of age) as compared to those housed at higher densities. This may be explained by higher feeder space per bird, allowing them easier access to the feeder during the day, thereby increasing their feeding frequency. There was a quadratic effect of period within each cage density on feed intake, 


\begin{tabular}{|c|c|c|c|c|c|c|c|}
\hline \multirow[t]{2}{*}{ Parameter } & \multirow[t]{2}{*}{ Density } & \multicolumn{5}{|c|}{ Periods $^{1}$} & \multirow[b]{2}{*}{ Mean $^{1}$} \\
\hline & & 1 & 2 & 3 & 4 & 5 & \\
\hline \multicolumn{8}{|l|}{$\begin{array}{l}\text { Feed intake } \\
\text { (g/bird/day) }\end{array}$} \\
\hline \multirow[t]{4}{*}{$C V \%=3.04$} & 10 & $112.96 \mathrm{~B}$ & $111.74 \mathrm{~B}$ & $109.41 \mathrm{~A}$ & 109.88B & $114.10 \mathrm{C}$ & 111.61 \\
\hline & 12 & 107.13A & $107.37 \mathrm{AB}$ & $106.22 \mathrm{~A}$ & $107.86 \mathrm{~B}$ & $108.60 \mathrm{~B}$ & 107.43 \\
\hline & 14 & $103.33 \mathrm{~A}$ & $104.95 \mathrm{~A}$ & $107.72 \mathrm{~A}$ & $100.56 \mathrm{~A}$ & $101.48 \mathrm{~A}$ & 103.60 \\
\hline & Mean & 107.86 & 108.02 & 107.76 & 106.10 & 108.06 & \\
\hline \multicolumn{8}{|c|}{ Egg production (\%) } \\
\hline \multirow[t]{4}{*}{$C V \%=3.15$} & 10 & 89.60 & 86.56 & 85.80 & 79.46 & 76.79 & $83.64 \mathrm{a}$ \\
\hline & 12 & 88.84 & 86.90 & 84.15 & 82.14 & 78.79 & $84.16 a$ \\
\hline & 14 & 86.64 & 85.68 & 81.79 & 78.89 & 72.39 & $81.07 \mathrm{~b}$ \\
\hline & Mean² & 88.36 & 86.34 & 83.91 & 80.16 & 75.99 & \\
\hline \multicolumn{8}{|c|}{ Egg weight (grams) } \\
\hline \multirow[t]{4}{*}{$C V \%=1.78$} & 10 & 67.97 & 68.34 & 68.34 & 68.34 & 68.34 & 66.26 \\
\hline & 12 & 66.77 & 67.34 & 67.34 & 67.34 & 67.34 & 67.22 \\
\hline & 14 & 67.68 & 68.87 & 68.87 & 68.87 & 68.87 & 66.63 \\
\hline & Mean & 67.47 & 68.18 & 68.18 & 68.18 & 68.18 & \\
\hline \multicolumn{8}{|c|}{ Feed conversion, $\mathrm{g} / \mathrm{dz}$} \\
\hline \multirow[t]{4}{*}{$C V \%=4.61$} & 10 & 1.51 & 1.55 & 1.53 & 1.66 & 1.79 & $1.60 \mathrm{~b}$ \\
\hline & 12 & 1.45 & 1.48 & 1.51 & 1.58 & 1.66 & $1.53 \mathrm{a}$ \\
\hline & 14 & 1.44 & 1.47 & 1.58 & 1.53 & 1.68 & $1.54 \mathrm{a}$ \\
\hline & Mean & 1.46 & 1.50 & 1.54 & 1.59 & 1.71 & 1.56 \\
\hline \multicolumn{8}{|l|}{$\begin{array}{l}\text { Feed } \\
\text { conversion, g/g }\end{array}$} \\
\hline \multirow[t]{4}{*}{$C V \%=5.20$} & 10 & 1.86 & 1.89 & 1.87 & 2.03 & 2.18 & 1.96 \\
\hline & 12 & 1.81 & 1.84 & 1.88 & 1.96 & 2.05 & 1.90 \\
\hline & 14 & 1.77 & 1.78 & 1.92 & 1.86 & 2.04 & 1.87 \\
\hline & Mean ${ }^{2}$ & 1.81 & 1.83 & 1.89 & 1.95 & 2.09 & 1.91 \\
\hline
\end{tabular}

1 - Means followed by different small letters in the same column are statistically different by Tukey's test $(p<0.01)$.

which was completely unexpected, as layers tend to increase their feed intake as they age.

Similar results were reported by Cunningham et al. (1988), who verified a $2.1 \%$ reduction in egg production/bird/day when increasing bird density from 406 to $316 \mathrm{~cm}^{2} /$ bird. Garcia et al. (1993), Adams \& Craig (1985), Davami et al. (1987), and Okpokho et al. (1987) also found that increasing bird density and reducing feeder space /bird resulted in lower egg production.

Opposite egg weight results were reported by Roush et al. (1984), who observed an increase in egg weight as cage area per bird decreased. Cunningham (1982), however, reported that densities of 483.87 and $387.09 \mathrm{~cm}^{2} / \mathrm{bird}$, in deep cages and of 484.15 and $387.32 \mathrm{~cm}^{2} / \mathrm{bird}$ in shallow cages did not affect egg weight.

Similar FCR results were reported by Hill (1977), who found an improvement of feed conversion per kilogram when increasing bird density from 464 to $310 \mathrm{~cm}^{2} / \mathrm{bird}$. On the other hand, Adams \& Craig (1985), Davami et al. (1987), Cunningham \& Ostrander (1982), and Garcia et al. (1993) found better feed conversion per dozen and per kilogram eggs yielded with increasing available cage space per bird (lower density).

The results obtained in the present study show that the highest density increased bird mortality, which is an important factor when production cycles are analyzed. Therefore, as only feed intake and FCR per $\mathrm{kg}$ results of the intermediate density of 12 birds per cage $\left(375 \mathrm{~cm}^{2} / \mathrm{bird}\right)$ were significantly different from the other evaluated densities, this suggests that this bird density makes the best use of the facilities, and therefore it is the most adequate for egg production under the conditions in which the present study was carried out.

\section{CONCLUSIONS}

The results of the present study indicate that 375 $\mathrm{cm}^{2} /$ bird up to 45 weeks of age and $450 \mathrm{~cm}^{2} /$ bird after 45 weeks of age are the best suited densities to maintain layer production parameters and livability.

Although cage density influenced feed intake, egg production, and feed conversion ratio, egg weight was not affected by reducing cage space per bird. 


\section{Rios RL, Bertechini AG, Carvalho JCC, Castro SF, Costa VA}

\section{REFERENCES}

Adams AW, Craig JV. Effect of crowding and cage shape on productivity and profitability of caged layers: A Survey. Poultry Science 1985; 64(2):238-242.

Al-Rawi B, Craig JV, Adams AW. Agonistic behavior and egg production of caged layers: genetic strain and group size effects. Poultry Science 1976; 55(2):796-07.

Carey JB, Kuo FL, Anderson KE. Effects of cage population on the productive performance of layers. Poultry Science 1995; 74(2):633-637

Craig JV, Milliken GA. Further studies of density and group size effects in caged hens of cage $s$ differing in fearful behavior: productivity and behavior. Poultry Science 1989; 68(1):9-16.

Cunningham DL. Cage type and density effects on performance and economic factors of caged layers. Poultry Science 1982; 61(10):1944-1949.

Cunningham DL, Ostrander CE. The effects of strain and cage shape and density on performance and fearfulness of white leghorn layers. Poultry Science 1982; 61(2):239-243.

Cunningham DL, Van Tienhoven A, Gvaryahu G. Population size, cage area, and dominance rank effects on productivity and webbeing of laying hens. Poultry Science 1988; 67(3):399-406.

Davami A. et al. Effects of population size, floor space, and feeder space upon productive performance, external appearance, and plasma corticosterone concentration of laying hens. Poultry Science1987; 66(2):251-257.

Dorminey RW, Arscott GH. Effects of bird density, nutrient density and perches on the performance of caged white leghorn layers. Poultry Science 1971; 50(2):619-626.

Ferreira DF. Análises estatísticas por meio do SISVAR para Windows versão 4.0. Anais da $45^{a}$ Reunião Anual da Região Brasileira da Sociedade Internacional de Biometria; 2000; São Carlos, São Paulo. Brasil. São Carlos: UFSCar; 2000. p.255-258.

Garcia EA, Aguiar IS, Politi ES. et al. Efeito da taxa de lotação da gaiola sobre a produtividade de poedeiras brancas. Anais da $93^{a}$ Conferência Apinco de Ciência e Tecnologia Avícolas; 1993; Santos, São Paulo. Brasil. p.71.

Goodling AC, Satterlee DG, Cerniglia GJ. et al. Influence of toeclipping and cage density on laying hen performance. Poultry Science 1984; 63(9):1722-1731.

Hill AT. The effects of space allowance and group size on egg production traits and profitability. British Poultry Science 1977; 17:483-492.

Lee K. Laying performance and fear response of white leghorns as influenced by floor space allowance and group size. Poultry Science 1989; 68(1):1333-36.
Effect of Cage Density on the Performance of 25- to 84Week-Old Laying Hens

Lohamnn. Manual de criação e manejo da linhagem Lohmann. Uberlândia: Granja Planalto; 1999.

Marks HL, Tindell LD, Olwe RH. Performance of egg production cage s under three cages densities. Poultry Science 1970; 49(4):1094-1100.

Mench JA, Teinhoven AV, Marsh JA. et al. Effects of cage and floor pen management on behavior, production, and physiological stress responses of laying hens. Poultry Science 1986, 65(6):10581069.

Okpokho NA, Craig JV, Milliken GA. Density and group size effects on cage hens of two genetic cage $s$ differing in escape and avoidance behavior. Poultry Science 1987; 66(12):1905-1910.

Robinson D. Effects of cage shape, colony size, floor area and cannibalism preventatives on laying performance. British Poultry Science 1979; 20:345-356.

Roush WB, Mashaly MM, Graves HB. Effect of increased bird population in a fixed cage area on production and economic responses of single comb white leghorn laying hens. Poultry Science 1984; 63(1):45-48.

Wells RG. Studies on cage arrangements for caged layers. World's Poultry Science 1971; 27:361-366. 